P-ISSN: 2615-1723

E-ISSN: 2615-1766

Oktober 2019
Jurnal Riset Pendidikan Dasar

02 (2), (2019) 89-93

Submitted: Juli, Accepted Agustus, Published: Oktober

\title{
Peningkatkan Partisipasi melalui Model PBL Berbantu Media Kartu Masalah Kelas IV Tema 8 Sekolah Dasar
}

\author{
Arwin Elfani Fitriana*, Sri Harmianto, \& Okto Wijayanti \\ Pendidikan Guru Sekolah Dasar, Universitas Muhammadiyah Purwokerto, Indonesia, \\ *Korespondensi. E-mail: Fitriana.elfani05@gmail.com
}

\begin{abstract}
Abstrak
Latar belakang penelitian ini adalah rendahnya partisipasi belajar siswa. Penelitian ini bertujuan untuk meningkatkan partisipasi belajar siswa melalui model pembelajaran Probem Based Learning (PBL) berbantu media kartu masalah. Penelitian ini dilaksanakan dalam beberapa tahap antara lai tahap perencanaan, tindakan, observasi dan refleksi. Subjek dalam penelitian ini adalah siswa kelas IV SD Negeri 2 Jatilawang yang berjumlah 31 siswa yang terdiri dari 14 siswa laki-laki dan 17 siswa perempuan. Alat pengumpulan data yang digunakan adalah lembar observasi partisiasi siswa, lembar observasi aktivitas guru, lembar observasi aktivitas siswa dan lembar evaluasi siswa. Hasil peningkatan terjadi pada setiap siklusnya. Peningkatan ini menunjukkan bahwa penggunaan model pembelajaran Problem Based Learning (PBL) berbantu media kartu masalah dapat meningkatkan partisipasi belajar siswa pada tema 8 Daerah Tempat Tinggalku di kelas IV SD Negeri 2 Jatilawang, Kecamatan Wanayasa, Banjarnegara. Hasil observasi partisipasi siswa pada siklus I yaitu 2,57, presentase ketuntasan 12,9\% dengan kriteria kurang baik meningkat pada siklus II menjadi 3,52, presentase ketuntasan 74,19\% dengan kriteria baik. Presentase ketuntasan partisipasi belajar siswa telah mencapai indikator keberhasilan yang telah ditentukan dengan kriteria baik dan meningkat.
\end{abstract}

Kata Kunci: Partisipasi; PBL; Kartu masalah.

\section{Increased Participation Through PBL Assisted Model Media Card Problem Class IV Theme 8 Elementary Schools}

\begin{abstract}
The background of this research was caused of the low of student's learning participation. The aim of this research is to improve students' learning participation through pbl model with media problem card at grade IV Theme 8. This research was implemented through some steps that weree planning, implementing, observing and reflecting step. The subject of this research was students at grade IV in elementary school 2 jatilawang with total numbers 31 students consist of 14 men and 17 women. The instruments of collecting data were students' participation observation sheet, teacher's activity observation sheet, students' activity observation sheet and students evaluation sheet. The result of the improvements happened in each cycle. This improvement showed that the use of problem based learning method with media problem card could improve students' learning participation in theme 8 Tempat Tinggalku in class VI Elementary school 2 Jatilawang, Wanayasa, banjarnegara. The result of the observation improved in cycle 11 became 3,52 , percentage completeness $74,19 \%$ in good criterion. The students learning participation percentage completeness has reached the indicator of success that has specified in good criterion and improvement
\end{abstract}

Keywords: Participation, PBL, Problem Card

Copyright (2019, JRPD, ISSN 2615 - 1723 (Print), ISSN 2615 - 1766 (Online) 


\section{Jurnal Riset Pendidikan Dasar, 02 (2), Oktober 2019 (89-93)}

Arwin elfani fitriana, Sri Harmianto, \& Okto Wijayanti

\section{PENDAHULUAN}

Kurikulum 2013 menerapkan pembelajaran tematik terpadu berlandaskan pada Permendikbud Nomor 65 Tahun 2013 tentang Standar Proses Pendidikan Dasar dan Menengah yang menyatakan bahwa Standar Kompetensi Lulusan yang diterapkan dan Standar Isi, membuat prinsip pembelajaran yang digunakan mulai dari pembelajaran terpisah-pisah menjadi satu padu atau saling menyambung satu sama lain.

Pembelajaran Kurikulum 2013 mengharapkan pembelajaran yang ditujukan untuk perkembangan kelebihan yang ada pada diri siswa menjadi manusia yang berguna bagi kehidupan. Kurikulum 2013 mempunyai banyak ciri khas salah satunya yaitu pembelajaran yang berpusat pada siswa atau Student Centered Learning.

Perubahan pola pembelajaran satu arah menjadi pembelajaran interaktif. Pembelajaran berpusat pada siswa menjadi pendekatan wajib bagi pembelajaran kurikulum 2013, siswa dituntut untuk belajar tidak bergantung dengan guru seperti pembelajaran klasikal. Kesiapan siswa untuk mengikuti pembelajaran berbasis tematik masih minim, sehingga menimbulkan permasalahan pada proses pembelajaran. Permasalahan terkait pada pembelajaran terpadu di sekolah terjadi di SD Negeri 2 Jatilawang.

Berdasarkan hasil observasi yang dilakukan dengan guru dan siswa kelas IV SD Negeri 2 Jatilawang, dapat diidentifikasi permasalahan pembelajaran di kelas yaitu partisipasi belajar siswa yang kurang. Indikator permasalahan partisipasi dapat dilihat antara lain siswa tergolong pasif dalam pembelajaran, cenderung tidak merespon perintah dari guru, dan kurang komunikatif dengan teman satu kelompok serta enggan untuk memberikan tanggapan. Siswa tidak sungguh-sungguh dalam mengerjakan tugas dari guru dan motivasi untuk belajar masih rendah. Siswa kurang memiliki sikap toleransi dalam menghargai pendapat orang lain dan kurang bertanggung jawab sebagai anggota kelompok.

Hasil observasi di atas menunjukkan bahwa partisipasi siswa sangat kurang. Keadaan yang demikian membuat proses pembelajaran tematik khususnya pada kelas IV SD Negeri 2 Jatilawang tidak mengalami kemajuan. Peran guru dalam pembelajaran belum menggunakan model pembelajaran yang lebih menarik dan tidak menggunakan media pembelajaran. Permasalahan yang ada di kelas IV berdampak pada proses pembelajaran dan menyebabkan partisipasi belajar siswa perlu untuk diperhatikan.

Hasil diskusi peneliti dengan guru kelas IV SD Negeri 2 Jatilawang, yaitu disepakati bahwa permasalahan terkait rendahnya partisipasi belajar siswa di kelas IV di SD Negeri 2 Jatilawang harus segera diatasi. Peneliti dan guru memutuskan untuk melakukan kolaborasi atau kerjasama dalam upaya meningkatkan partisipasi belajar siswa dengan proses pembelajaran menggunakan metode pembelajaran yang berbeda dari metode yang pernah guru digunakan, dan tetap beriringan dengan pembelajaran pada Kurikulum 2013. Salah satu langkah yang akan dilakukan oleh peneliti untuk meningkatkan partisipasi belajar siswa yaitu dengan menggunakan model pembelajaran Problem Based Learning berbantu media pembelajaran kartu masalah.

$$
\text { Model Problem Based Learning }
$$
diharapkan dapat meningkatkan partisipasi belajar karena pada setiap tahapan pembelajaran, siswa diajak untuk aktif melakukan diskusi kelompok dan siswa akan belajar memecahkan masalah yang akan mengasah kemampuan siswa untuk ikut berperan dalam proses pembelajaran.

Hamruni (2011: 104) menyatakan bahwa pembelajaran berbasis masalah merupakan suatu model pembelajaran yang menggunakan masalah dunia nyata sebagai suatu konteks bagi siswa untuk belajar tentang Copyright C2019, JRPD, ISSN 2615 - 1723 (Print), ISSN 2615 - 1766 (Online) 
cara berpikir kritis dan keterampilan pemecahan masalah, serta untuk memperoleh pengetahuan dan konsep yang esensial dari materi pelajaran di sekolah.

Model Problem Based Learning (PBL) mengharapkan siswa agar lebih aktif lagi dalam berbagai aktivitas pembelajaran, semua siswa dapat aktif dan merasakan langsung proses pembelajaran. Sehingga pembelajaran akan lebih bermakna dan menarik bagi siswa. Selain itu dengan menggunakan media dapat mendukung proses pembelajaran, maka perlu adanya penggunaan media pembelajaran yang mendukung. Diantara banyak media yang digunakan, salah satu media yang digunakan yaitu media kartu masalah, dengan tujuan pembelajaran lebih menarik dan siswa mudah untuk memahami pembelajaran yang berlangsung, serta dapat meningkatkan keinginan siswa untuk berpartisipasi dalam pembelajaran dan meningkatkan prestasi belajar siswa di kelas IV SD Negeri 2 Jatilawang. Penggunaan media pembelajaran kartu masalah mendukung proses pembelajaran dengan inovasi yang berbeda dan lebih menarik. Media pembelajaran kartu masalah yang digunakan guru dan peneliti adalah jenis media pembelajaran dengan konsep pemecahan masalah dan melibatkan aktivitas siswa. Penggunaan media kartu masalah digunakan pada saat berlangsungnya tahapan model pembelajaran Problem Based Learning pada pembelajaran di kelas IV SD Negeri 2 Jatilawang.

Berdasarkan uraian permasalahan tersebut, maka peneliti dan guru bersepakat untuk melakukan upaya perbaikan pembelajaran dengan mengadakan Penelitian Tindakan Kelas (PTK). Penelitian ini bertujuan untuk meningkatkan partisipasi belajar siswa pada tema 8 Daerah Tempat Tinggalku meggunakan model pembelajaran Problem Based Learning (PBL) dengan bantuan media kartu masalah pada siswa kelas IV SD Negeri 2 Jatilawang.

\section{METODE}

Jenis penelitian ini adalah Penelitian Tindakan Kelas (PTK). Penelitian ini dilaksanakan di Kelas IV SD Negeri 2 Jatilawang, Kecamatan Wanayasa, Kabupaten Banjarnegara dengan melibatkan beberapa pihak seperti guru dan observer. Teknik dan alat pengumpulan data berupa observasi, dokumentasi dan tes tertulis. Alat pengumpulan data menggunakan lembar observasi partisipasi. Lembar observasi partisipasi digunakan sebagai alat untuk pengumpulan data partisipasi siswa, selama melaksanakan observasi.

Penelitian ini menggunakan model PTK menurut Kemmis dan Mc Taggart (1982:7) dipaparkan bahwa terdapat satu kali putaran yang terdiri atas empat bagian yaitu perencanaan (planning), tindakan (action), observasi (observing) dan refleksi (reflecting). Penelitian ini dilakukan dalam 2 siklus yang pada setiap siklusnya terdiri atas dua kali pertemuan. Setiap siklus terdiri atas 4 langkah yaitu: Perencanaan (planning), Pelaksanaan dan Pengamatan (Acting and Observing), dan Refleksi (Reflecting).

\section{HASIL DAN PEMBAHASAN}

Hasil penelitian ini menemukan bahwa terdapat peningkatan partisipasi dan prestasi belajar siswa melalui model pembelajaran Problem Based Learning (PBL) berbantu media kartu masalah. Hal tersebut dibuktikan dengan meningkatnya partisipasi siswa selama proses pembelajaran melalui lembar observasi. Sehingga prestasi belajar siswa meningkat.

Menurut Bern dan Erickson dalam Komalasari (2011: 59) menyatakan bahwa PBL ini merupakan strategi dalam kegiatan belajar mengajar yang melibatkan siswa dalam memcahkan segala permasalahan dengan cara menyatukan berbagai konsep serta keterampilan yang dimiliki siswa dari berbagai ilmu. Stategi dalam PBL diantaranya mengumpulkan serta menyatukan segala 
informasi yang dimiliki lalu mempresentasikan setiap penemuannya agar siswa dapat berpatisipasi dalam proses pembelajaran yang berlangsung.

Adapun tujuan dari model Problem Based Learning menurut Ibnu (2015:70) antara lain:

a. Individu dapat memiliki keterampilan berpikir dan keterampilan pemecahan ketika dihadapkan dengan masalah.

b. Individu belajar berperan menjadi orang dewasa yang autentik.

c. Menjadi seorang pembelajar yang mandiri. Tujuan tersebut beriringan dengan upaya agar siswa dapat meningkatkan partisipasi belajar.

Menurut Rusman

menyatakan bahwa partisipasi belajar adalah kegiatan belajar yang melibatkan siswa secara optimal untuk belajar saling membantu atau ikut berpatisipasi dalam melakukan kegiatan bersama. Kegiatan pembelajaran yang optimal akanmembangun partisipasi siswa sehingga pembelajaran menjadilebih aktif dan bermakna bagi siswa. Untuk mengukur partisipasi, dilakukan dengan cara melakukan observasi pada siswa.

Sejalan dengan pendapat diatas Mulyasa (2009: 241) menyatakan bahwa partisipasi adalah keterlibatan peserta didik dalam perencanaan, pelaksanaan, dan evaluasi pembelajaran. Pelaksanaan pembelajaran partisipatif, guru hendaknya berperan sebagai fasilitator saja dengan memberikan kemudahan siswa dalam kegiatan belajar melalui langkah-langkah diantaranya seperti menciptakan suasana belajar yang membuat siswa untuk siap belajar; ikut membantu siswa dalam menyusun anggota kelompok agar ketika pelaksanaan dapat saling membantu; guru membantu siswa dalam menemukan apa yang dibutuhkan ketika belajar; guru membantu siswa untuk mencapai tujuan belajar; guru membantu siswa dalam proses kegiatan belajar atau mengerjakan tugas; guru membantu siswa ketika mengevaluasi diri terhadap proses dan hasil belajar yang dilakukan.

Siswa memiliki partisipasi yang baik dapat dilihat dengan indikator partisipasi. Menurut Sudjana (Taniredja, 2010:97) menyatakan bahwa kegiatan partisipasi yang dilaksankan perlu diamati pelaksanaan ketika membuat pedoman aktivitas siswa diantaranya yaitu dalam memberikan pendapat ketika proses PBL untuk pemecahan masalah; dapat memberikan tanggapan atau respon terhadap apa yang dikatakan orang lain; siswa dapat mengerjakan tugas yang diberikan oleh guru; siswa dapat termotivasi dalam mengerjakan tugas; siswa memiliki sikap toleransi yang tinggi dan mau menerima pendapat dari orang lain; siswa memiliki sikap tanggung jawab

Peningkatan partisipasi siswa melalui lembar observasi yang dilakukan observasi oleh observer 3 . Hasil peningkatan tersebut dapat dilihat pada gambar partisipasi siswa di SD Negeri 2 Jatilawang pada gambar 1.1 dibawah ini:

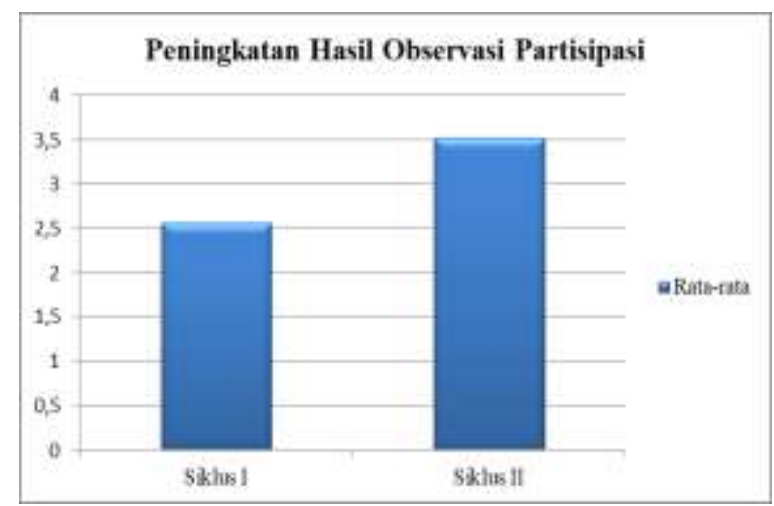

Gambar 1 Histogram Peningkatan Partisipasi

Berdasarkan gambar 1 menunjukkan bahwa partisipasi belajar siswa mengalami perubahan pada siklus I sampai dengan siklus II. Skor rata-rata pada siklus I sejumlah 2,57 dengan kriteria kurang baik meningkat menjadi 3,52 dengan kriteria baik pada siklus II. Peningkatan partisipasi tersebut dibuktikan dengan hasil observasi yang telah didapat. Pada saat Penelitian Tindakan Kelas (PTK) sikap partisipasi siswa diukur menggunakan 


\section{Jurnal Riset Pendidikan Dasar, 02 (2), Oktober 2019 (89-93)}

Arwin elfani fitriana, Sri Harmianto, \& Okto Wijayanti

lembar observasi yang telah disesuaikan oleh guru pada setiap pertemuan.

Sejalan artikel jurnal yang dilakukan oleh Gamze Sezgin (2010: 711) yang berjudul "The effects of problem-based learning on preservice teachers' achievement, approaches and attitudes towards learning physics" dari Dokuz Eylul University, Buca, Izmir, Turkey menjelaskan bahwa dalam penelitiannya bertujuan untuk mengetahui dampak penggunaan pembelajaran berbasis masalah pada prestasi siswa dan sikap terhadap belajar fisika. Hasil penelitian ini menunjukkan bahwa menggunakan pembelajaran berbasis masalah tidak hanya mendorong siswa untuk belajar saja, tetapi juga meningkatkan minat siswa terhadap belajar fisika serta penggunaan PBL berdampakpada prestasi siswa dalam pembelajaran fisika secara positif.

\section{SIMPULAN}

Berdasarkan hasil penelitian dan pembahasan dapat disimpulkan; (1) Model pembelajaran Problem Based Learning (PBL) dapat meningkatkan partisipasi belajar siswa. peningkatan ini terbukti dari hasil yang diperoleh dari lembar observasi yang diisi oleh observer 3 melalui pengamatan disetiap pembelajaran. (2) Hasil pada siklus I partisipasi siswa diperoleh presentase 12,9\% dengan kriteria kurang baik, pada siklus II diperoleh presentase $74,19 \%$ dengan kriteria baik.

\section{DAFTAR PUSTAKA}

Ibnu, T. (2015). Mendesain Model Pembelajaran Inovatif, Progresif, Dan Kontekstual. Jakarta: Prenada Media Group

kemmis, S \& Mc Taggart. (1984). The Action Research Planner. Victoria: Deakin University.

Komalasari. (2011). Pembelajaran Kontekstual Konsep Dan Aplikasi. Bandung: Rafika Aditama.
Mulyasa, E. (2009). Kurikulum Yang Disempurnakan. Bandung: PT Remaja Rosdakarya

Rusman. (2011). Model-Model Pembelajaran Mengembangkan Profesionalisme Guru. Jakarta: PT Raga Grafindo Persada .

Sezgin, G. (2010). "The Effects Of Problem Based Learning On Preservice Teachers Achievement, Approaches And Attitudes Towards Learning Physics". International Journal Of Physical Sciences. Vol 5 